\title{
Analysis of Language Features of Zhang Peiji's Translated Version of The Sight of Father's Back Written by Zhu Ziqing
}

\author{
Jianjun Wang ${ }^{1, *} \&$ Yixuan Guo ${ }^{1}$ \\ ${ }^{1}$ College of Foreign Languages, Inner Mongolia University, Hohhot, China \\ *Correspondence: College of Foreign Languages, Inner Mongolia University, 24 Zhaojun Road, Yuquan District, \\ Hohhot 010070, P. R. China. Tel: 86-471-499-3241. E-mail: kingjjpt@163.com
}

Received: April 22, 2016

Accepted: May 12, 2016 Online Published: May 29, 2016

doi:10.5430/wjel.v6n2p19

URL: http://dx.doi.org/10.5430/wjel.v6n2p19

\begin{abstract}
Zhu Ziqing's The Sight of Father's Back enjoys high reputation and has been translated into various versions by a lot of translators, including Zhang Peiji, Yang Xianyi and Gladys Yang and so on. Concerning all the versions, this paper aims to analyze language features of Zhang Peiji's translated version of The Sight of Father's Back. It mainly sets out from language features. It analyzes features of word selection in this translation by some examples which can reflect features very well. This is the way in which the authors conduct this paper. Through this paper, the authors aim to find out different language features of prose translation and thus conclude some experiences for further studies in the related aspect in the future.
\end{abstract}

Keywords: The Sight of Father's Back; Zhu Ziqing; Zhang Peiji's translated version; language feature; word selection

\section{Introduction}

Prose writing has had a long history in China. After "The May Fourth Movement" in China, it began to flourish as poetry writing did. Translation of Chinese prose still lacks enough studies though some of researchers in the translation field have studied it. Translation of Chinese prose still has a long way to go. A good prose translation can to some extent make Chinese culture and national spirit spread quite well in the world. There are many different aspects of prose translation for researchers in this field to study. "Lexical cohesion as an important cohesive device plays a major role in achieving discourse coherence." (Zhang Xiaocui \& Wang Zhen, 2012: 107) "Different stylistic features by different literary works are mainly manifested at the levels of lexicon, syntax and discourse. The study of style begins with words. Zhu Ziqing's style is reflected at the level of lexicon by colloquial words." (Zhang Lijuan, 2001: 150) While, this paper aims to analyze Zhang Peiji's translated version of The Sight of Father's Back written by Zhu Ziqing from the perspective of its word selection. By doing this, the authors hope that translation researchers can realize there is still much room in Chinese prose translation to study and thus can make more contribution to Chinese prose translation. In writing the paper, firstly, the authors set out from the aspect of word selection, choose some typical sentences in the translation and analyze them in detail and conclude some points in word selection. Through an analysis of features of word selection, the conclusion can be made: Zhang Peiji's translation of The Sight of Father's Back is precise in word selection and can also reflect the vivid scenes of the original. Its sentence structures are closely connected and related to the original. It enables readers to imagine the original scenes as well as to have a general grasp of the original. After the analysis, the authors find out that prose seems to be easier to be translated compared with poetry, but there are a lot of things which should be noted. Moreover, a good prose translation can not only reproduce the original scenes truthfully but also make readers feel on the scene personally. This kind of translation can be called a better one. Therefore, this kind of translation is also worth studying.

\section{Analysis of Its Language Features - Word Selection}

In the process of translation, the first step is to understand the original correctly. Only on the basis of a correct understanding can translation techniques be used in the course of translation. This prose is Zhu Ziqing's early work, therefore some of ancient Chinese were utilized. Zhang Peiji's translated version obeys the rule of translation after a correct understanding. (Hu Yan \& Zhang Heng, 2009: 105) In this part, the authors choose some examples ranging from the 
translation of noun, verb and phrase which are precise and vivid in word selection and then analyze them one by one. Both its original text and translated version are placed in the following.

Example 1:

Original text: 我与父亲不见已二年余了, 我最不能忘记的是他的背影。

Zhang's version: It is more than two years since I last saw father, and what I can never forget is the sight of his back.

In this sentence, Zhang Peiji translated “他的背影” into “the sight of his back”, in which the word "sight” is accurate and vivid here. The word "sight" can not only make readers associate father's back with tallness and greatness but also make readers deeply feel the affection towards his father in the original. By contrast, if it is translated into "the back of my father", this seems to lack a kind of visualization and reproduction of the original scene, but just to highlight a part of father's body - the back, instead of the sight that father had left. Therefore, the use of the word "sight" reflects beauty of language and leaves room for readers to imagine.

Example 2:

Original text: 近几年来，父亲和我都是东奔西走，家中光景是一日不如一日。

Zhang's version: In recent years, both father and I have been living an unsettled life, the circumstances

of our family going from bad to worse.

In translating this sentence, Zhang used "unsettled life" to describe that both "father and I" were suffering from bad circumstances and had to go to different places to make a living. The word "unsettled" is just to the point. What's more, the phrase "from bad to worse" contains a comparative degree "bad - worse", which obviously reflects the circumstances in "our" family was bad before, and now it became worse. Comparison makes things clearly coming to readers.

Example 3:

Original text: 我读到此处, 在晶荣的泪光中, 又看见那肥胖的、青布棉袍黑布马补的背影。

Zhang's version: Through the glistening tears which these had brought to my eyes I again saw the back of father's corpulent form in the dark blue cotton-padded cloth long gown and the black cloth mandarin jacket.

This is the last time that Zhu Ziqing referred to his cry. Zhang Peiji used "glistening tears" here to show the tears were glittering, through which the sight of father's back was appearing again in Zhu Ziqing's mind. It can indicate Zhu Ziqing missing his father so much as well as his deepest love to his father.

Example 4:

Original text: 那年冬天, 祖母死了, 父亲的差使也交卸了, 正是祸不单行的日子, 我从北京到徐 州, 打算跟 着父亲奔丧回家。

Zhang's version: Misfortunes never come singly. In the winter of more than two years ago, grandmother died and father lost his job. I left Beijing for Xuzhou to join father in hastening home to attend grandmother's funeral.

In the translation of this sentence, Zhang Peiji used two words: "join in" and "hastening". The use of "join in" indicates that Zhu Ziqing and his father were in different places, he went from his place and met his father in another place. That is to say, he had to leave Beijing for Xuzhou. Moreover, by using a word "hastening" Zhang expressed the urgent state that Zhu Ziqing was in after receiving the message that his grandmother died and preferred to go back home immediately. But, if "hastening" is replaced by the word "going back", it will be a totally different conception. The word "going back" lacks the atmosphere that Zhu Ziqing intended to express, and cannot present the related conception reasonably.

Example 5:

Original text: 到了徐州见着父亲, 看见满园狼藉的东西, 又想起祖母，不禁籁籁地流下眼泪。

Zhang's version: When I met father in Xuzhou, the sight of the disorderly mess in his courtyard and the thought of grandmother started tears trickling down my cheeks.

Here Zhang unfolded a visual scene of tears coming down like a trickle by using the word "trickling", which lively shows Zhu Ziqing's unwillingness to see his father's tough situation as well as intense emotion to his grandmother. The translation truthfully reproduces the scene of Zhu Ziqing's crying with tears out of control, and describes the deepest family affection visually.

Example 6: 
Original text: 回家变卖典质, 父亲还了亏空, 又借钱办了丧事。

Zhang's version: After arriving home in Yangzhou, father paid off debts by selling or pawning things. He also borrowed money to meet the funeral expenses.

It is well known that there was a line called "pawn" in the past in China, but foreigners are not familiar with this. So, when translating this kind of sentences that contain such traditional Chinese culture, special attention should be paid to giving consideration to foreigners' acceptability. Zhang translated “变卖典质” here into "selling or pawning”, which is not only easy to be understood but also a means of publicizing traditional Chinese culture to some extent. In addition, Zhang described a cheerless atmosphere in Zhu Ziqing's family through the phrase "meet the funeral expenses". It shows that the circumstances in the family was too bad to afford the funeral expenses, which makes readers feel as if they were on the spot with Zhu Ziqing.

Example 7:

Original text: 他用两手攀着上面, 两脚再向上缩; 他肥胖的身子向左微倾, 显出努力的样子, 这时我看见他 的背影，我的眼泪很快地流下来了。

Zhang's version: His hands held onto the upper part of the platform, his legs huddled up and his corpulent body tipped slightly towards the left, obviously making an enormous exertion. While I was watching him from behind, tears gushed from my eyes.

In translating this sentence, Zhang used a series of verbs to describe how difficult "father" was to climb onto the platform. He used "held onto", "huddled up" and "tipped slightly", which can show readers a vivid picture that "father" was climbing onto the platform, arousing readers' compassion for "father" at the same time. Besides, when describing Zhu Ziqing's cry in this sentence, Zhang used "tears gushed from my eyes", which is different from the previous phrase "tears trickling down my cheeks". According to the dictionary, a gush of liquid is a sudden, rapid flow of liquid or a quantity of it that suddenly flows out. Compared with the previous cry, the cry of this time is intenser, showing Zhu Ziqing's deep sorrow at the sight of his father.

Example 8:

Original text：过铁道时，他先将橘子散放在地上，自己慢慢爬下，再抱起橘子走。

Zhang's version: In crossing the railway track, he first put the tangerines on the ground, climbed down slowly and then picked them up again.

In this sentence, Zhu Ziqing used a series of verbs to describe the scene that his father was crossing the railway after buying tangerines, such as “散放”、“爬下”、“抱起”. Zhang also used several verb phrases such as “put...on the ground”, "climbed down" and "picked up" in his translation. Translating these three phrases almost successively can reach the target of cumulative progression, fluentness and unity with the original in form and in effect.

Example 9:

Original text: 这些日子，家中光景很是惨淡，一半为了丧事，一半为了父亲赋闲。

Zhang's version: Between grandma's funeral and father's unemployment, our family was then in reduced circumstances.

In translating this sentence, the word "reduced" in the expression "in reduced circumstances" not only illustrates the present circumstances in the family were much worse compared with the previous years' but also can foresee the circumstances were going to be worse and worse. The way like this that expresses more than one single meaning by using just one word is quite useful and effective.

Example 10:

Original text: 到南京时, 有朋友约去游逛, 勾留了一日; 第二日上午便须渡江到浦口, 下午上车北去。

Zhang's version: I spent the first day in Nanjing strolling about with some friends at their invitation, and was ferrying across the Yangtze River to Pukou the next morning and thence taking a train for Beijing on the afternoon of the same day.

In this sentence, Zhang utilized the phrase "strolling about" to illustrate that Zhu Ziqing, along with other friends, hung about aimlessly, instead of doing something on purpose. "Strolling about" here is used quite appropriately.

Example 11: 
Original text: 我那时真是聪明过分, 总觉他说话不大漂亮, 非自己插嘴不可, 但他终于讲定了价钱; 就送我 上车。

Zhang's version: I was then such a smart aleck that I frowned upon the way father was haggling and was on the verge of chipping in a few words when the bargain was finally clinched.

If you describe someone as a smart aleck, you dislike the fact that he thinks that he is very clever and always has an answer to everything. So such an expression "smart aleck" contains a kind of ironic meaning. Zhang used it here to describe Zhu Ziqing's petty trick. He thought that his father could not do well in haggling with the porter over the fee, so he chipped in a few words to show he was a "smart aleck". By utilizing this expression, a sort of meaning is rendered, that is "father's" insignificance. Such contrast may lead readers' sympathy for the "father".

Example 12:

Original text: 我北来后, 他写了一封信给我, 信中说道: “我身体平安, 惟膀子疼痛厉害, 举箸提笔, 诸多不 便，大约大去之期不远矣。”

Zhang's version: After I arrived in Beijing, he wrote me a letter, in which he says: "I'm all right except for a severe pain in my arm. I even have trouble using chopsticks or writing brushes. Perhaps it won't be long now before I depart this life."

In Chinese, “大去之期” means the moment when a person died. But if translating this phrase into "die”, it lacks the elegance that a good translation needs. Anyway, Zhang translated it into "depart this life", which can not only make the reader understand but also make the translation elegant. This kind of translating technique is worth employing in the translation.

Example 13:

Original text: 我两三回劝他不必去, 他只说: “不要紧, 他们去不好!”

Zhang's version: I repeatedly tried to talk him out of it, but he only said:” Never mind! It won't do to trust guys like those hotel boys!"

In the original text, Zhu Ziqing just said “他们去不好”, but didn’t illustrate the reason why it was not good for those hotel boys to go together with "me". However, in Zhang Peiji's translated version, it added the distrust of Zhu Ziqing's father to those hotel boys that had been mentioned before. Therefore, Zhang translated it into "It won't do to trust guys like those hotel boys", which reliefs readers' wonder why it was not good to let those hotel boys to accompany with him, making the translation easy to be understood.

Example 14:

Original text: 我望着他走出去。他走了几步, 回头看见我, 说: “进去吧, 里边没人。”

Zhang's version: I gazed after his back retreating out of the carriage. After a few steps, he looked back at me and said: Go back to your seat. Don't leave your things alone."

In the original text, Zhu Ziqing's father just said: “Go back to your seat, and there's nobody inside." These words didn't seem to refer to the meaning that you do not leave your things alone. Anyway, though he did not say it directly, an implied meaning was hidden, that is "your things are alone, then you need to go back to your seat and take good care of them". Zhang noticed this implied meaning and translated it on a basis of the discourse, which can make the whole passage coherent and the expressiveness effective.

\section{Conclusion}

This paper studies language features of Zhang Peiji's translated version of The Sight of Father's Back written by Zhu Ziqing. In the paper, the authors mainly analyze the aspect of word selection. In the course of analysis, the authors give some examples that can obviously reflect the way that Zhang Peiji utilized words to make the translation well to the point. And the authors analyze how translated sentences become appropriate and even perfect by using various words. Through analyzing examples, a general conclusion is made: Zhang Peiji's translated version of The Sight of Father's Back is faithful, expressive and elegant in the aspect of selecting words. After studying how to select words and make sentences coherent and effective in the course of translation, some translation techniques about this respect can be put into practice later. 


\section{References}

Bassnett, Susan. (2004). Translation studies. Shanghai: Shanghai Foreign Language Education Press.

Bell, R. (1991). Translation and translating. London: Longman.

Gentzler, Edwin. (1993). Contemporary translation theories. London: Routledge.

Gile, D. (1995). Basic concepts and models for interpreter and translator training. Amsterdam and Philadelphia: John Benjamins. http://dx.doi.org/10.1075/btl.8(1st)

Hu Binyao. (2012). Translation quality assessment of The Sight of Father's Back. Journal of Changchun Institute of Technology, 13(3), 108-110.

Huang Tingting. (2011). Comparative study of words and phrases in two English versions of The Sight of Father's Back. Journal of Zhoukou Normal University, 28(4), 66-69.

Hu Yan \& Zhang Heng. (2009). On the English translation of The Sight of Father's Back. Journal of Jiangxi Institute of Education, 30(3), 105-108.

Jia Wenbo. (2005). On pragmatic translation with functionalist approach. Beijing: China Translation and Publishing Corporation.

Kiraly, D. (1995). Pathways to translation: Pedagogy and progress. Kent, OH: Kent University Press.

Liao Qiyi. (2002). Exploration of contemporary western translation theories. Nanjing: Yilin Press.

Liu Yafeng. (2009). Translator's adaptation and selection - translation process research for China's global communication. Shanghai: Shanghai International Studies University.

Meng Bei. (2010). An analysis of grammatical metaphor in Zhu Ziqing's “The Sight of Father's Back”. Journal of Harbin University, 31(10), 111-116.

Min Xihong \& Zhang Jianying. (2013). The style reproduction of Zhang Peiji's translation of The Sight of Father's Back. Journal of Changsha Railway University, 14(2), 133-134.

Newmark, P. (2001). Approaches to translation. Shanghai: Shanghai Foreign Language Education Press.

Nida, E. (2000). A fresh look at translation. In Beeby, A., D. Ensinger \& M. Presas. Investigating translation: Selected papers from the 4th international congress on translation, Barcelona. Amsterdam/Philadelphia: John Benjamins Publishing Company.

Nida, E.A. (1964). Toward a science of translating. Leiden: E.J. Brill.

Pym, A. (1998). Method in translation history. Manchester: St. Jerome.

Robinson, Dauglus. (2003). Becoming a translator: An introduction to the theory and practice of translation (2nd ed). London: Routledge.

Snell-Hornby, Mary. (2001). Translation studies: An integrated approach. Shanghai: Shanghai Foreign Language Education Press.

Toury, Gideon. (1995). Descriptive translation studies and beyond. Amsterdam: John Benjamins. http://dx.doi.org/10.1075/btl.4

Venuti, Lawrence. (1995). The translator's invisibility: A history of translation. London: Routledge. http://dx.doi.org/10.4324/9780203360064

Wang Tao. (2001). Practical course of English-Chinese \& Chinese-English translation. Wuhan: Wuhan University Press.

Zhang Lijuan. (2001). A critique on Mr. Zhang Peiji's English version of Bei Ying. Journal of Xianning Teachers College, 21(5), 149-152.

Zhang Peiji. (2007). Selected Modern Chinese Essays 1. Shanghai: Shanghai Foreign Language Education Press, 47-54.

Zhang Xiaocui \& Wang Zhen. (2012). A contrastive study of lexical cohesion in the Chinese and English version of The Sight of Father's Back. Journal of Lanzhou Polytechnic College, 19(6), 104-107.

Zhou Fangzhu. (2002). Principles of translation from English into Chinese. Hefei: Anhui University Press. 